\title{
PPO2 Mutations in Amaranthus palmeri: Implications on Cross-Resistance
}

\author{
Pâmela Carvalho-Moore ${ }^{1,2}{ }^{\mathbb{D}}$, Gulab Rangani ${ }^{1}$, James Heiser ${ }^{3}$, Douglas Findley ${ }^{4}$, Steven J. Bowe ${ }^{4}$ \\ and Nilda Roma-Burgos $1, *(\mathbb{D}$
}

1 Department of Crop, Soil and Environmental Sciences, University of Arkansas, Fayetteville, AR 72704, USA; pcarvalh@email.uark.edu (P.C.-M.); grangani@uark.edu (G.R.)

2 Former Cell and Molecular Biology Program, University of Arkansas, Fayetteville, AR 72704, USA

3 Fisher Delta Research Center, College of Agriculture, University of Missouri, Portageville, MO 63873, USA; heiserJ@missouri.edu

4 BASF Corporation, Research Triangle Park, NC 27709, USA; douglas.findley@basf.com (D.F.); steven.bowe@basf.com (S.J.B.)

* Correspondence: nburgos@uark.edu

Citation: Carvalho-Moore, P.;

Rangani, G.; Heiser, J.; Findley, D.;

Bowe, S.J.; Roma-Burgos, N.

PPO2 Mutations in Amaranthus

palmeri: Implications on

Cross-Resistance. Agriculture 2021, 11,

760. https://doi.org/10.3390/

agriculture 11080760

Academic Editor: Anna Andolfi

Received: 20 July 2021

Accepted: 5 August 2021

Published: 10 August 2021

Publisher's Note: MDPI stays neutral with regard to jurisdictional claims in published maps and institutional affiliations.

Copyright: (c) 2021 by the authors. Licensee MDPI, Basel, Switzerland. This article is an open access article distributed under the terms and conditions of the Creative Commons Attribution (CC BY) license (https:// creativecommons.org/licenses/by/ $4.0 /)$.

\begin{abstract}
In Arkansas, resistance to protoporphyrinogen IX oxidase (PPO)-inhibiting herbicides in Amaranthus palmeri S. Wats. is mainly due to target site mutations. Although A. palmeri PPO-mutations are well investigated, the cross-resistance that each ppo mutant endows to weed populations is not yet well understood. We aimed to evaluate the response of PPO-resistant A. palmeri accessions, harboring the ppo2 mutations $\triangle G 210$ and G399A, to multiple PPO-inhibiting herbicides. Six resistant and one susceptible field accessions were subjected to a dose-response assay with fomesafen, and selected survivors from different fomesafen doses were genotyped to characterize the mutation profile. The level of resistance to fomesafen was determined and a cross-resistance assay was conducted with 1 and 2 times the labeled doses of selected PPO herbicides. The accession with higher predicted dose to control $50 \%$ of the population (ED50) had a higher frequency of $\Delta G 210$-homozygous survivors. Survivors harboring both mutations, and those that were $\Delta G 210$-homozygous, incurred less injury at the highest fomesafen rate tested $\left(1120 \mathrm{~g}_{\text {ai ha }}{ }^{-1}\right)$. The populations with a high frequency of $\Delta G 210$ homozygous survivors, and those with individuals harboring $\Delta G 210+G 399 A$ mutations, exhibited high potential for cross-resistance to other PPO herbicides. The new PPO-herbicide chemistries (saflufenacil, trifludimoxazin) generally controlled the PPO-resistant populations.
\end{abstract}

Keywords: Amaranthus palmeri; protoporphyrinogen IX oxidase (PPO); herbicide resistance; targetsite resistance

\section{Introduction}

The commercialization of genetically modified crops resistant to the highly effective, non-selective herbicide glyphosate has greatly impacted weed management. Although chemical control has been the main weed control method prior to the release of herbicideresistant crops, the glyphosate-resistant technology allowed farmers to rely primarily on a single herbicide to control weeds, which reduced the diversity of weed management practices and chemistries used in a crop season [1-3]. Weed resistance to herbicides is the inevitable consequence of herbicide selection pressure. Relying on a single herbicide exerted tremendous selection pressure on weed populations, resulting in the evolution of many glyphosate-resistant weed species, including Amaranthus spp. [4,5]. The same is true with continuous use of herbicides with the same mode of action (MOA), as demonstrated by the global database on herbicide-resistant weeds [6].

Amaranthus palmeri S. Wats. (Palmer amaranth) is a highly competitive weed which is genetically compatible with other species in the Amaranthaceae family, including A. spinosus L. and A. tuberculatus (Moq.) Sauer [7-9]. A. palmeri is widely resistant to 
acetolactate synthase (ALS)- and 5-enolpyruvylshikimate-3-phosphate synthase (EPSPS)inhibiting herbicides. In at least ten cases, a single $A$. palmeri population carries multiple resistance to ALS herbicides and glyphosate [6,10-12]. Herbicides inhibiting protoporphyrinogen oxidase (PPO, EC 1.3.3.4) have been used extensively to control ALS- and glyphosate-resistant $A$. palmeri populations. By inhibiting this enzyme, PPO-inhibitor herbicides stop the oxidation of protoporphyrinogen IX into protoporphyrin IX, which leads to accumulation of protoporphyrinogen IX. The excess protoporphyrinogen IX is exported into the cytoplasm, where it reacts with free oxygen, producing a photosensitive protoporphyrin IX. Upon exposure to light, protoporphyrin IX generates singlet oxygen, ultimately leading to cellular death in susceptible plants [13-17]. The PPO enzyme exists in two forms in plants; PPO1 is located in the chloroplast, whereas PPO2 is in the mitochondria and, in a few species, also in the chloroplast [18,19].

A. palmeri is resistant to PPO-inhibitor herbicides primarily due to target-site (TSR) mechanisms and, to a lesser extent, via non-target-site resistance (NTSR) mechanisms. Mutations in PPO2 have been found in PPO-resistant Palmer amaranth. The first to be detected was the deletion of a glycine at position $210(\Delta G 210)$, reported in A. tuberculatus [12,20-22]. Second was a substitution of arginine with glycine or methionine at the 128th position (R128G or R128M) [11,23,24]. This mutation was identified in Ambrosia artemiisifolia L. [25]. The substitution of glycine with alanine at position 399 (G399A) was the latest resistance-conferring ppo2 mutation identified in A. palmeri [26].

Since $A$. palmeri is dioecious, it is an obligate outcrossing specie; thus, the accumulation of PPO mutations in the same plant via gene flow is expected. Indeed, some survivors of fomesafen treatment harbor $\Delta G 210+R 128 G$ mutations in the same plant [27]. The authors did not report the level of resistance in these plants or if the mutations co-occurred in the same allele. The occurrence of multiple PPO mutations in the same allele would be rare if such a combination would compromise the enzyme function. The most likely scenario is for different mutations to occur in different plants within a field population. In a study of PPO-resistant A. palmeri accessions from four states in the USA, accessions with more than one $p p o$ mutation were grouped in one cluster, and collectively exhibited stronger resistance [28]. Further evaluation revealed a few plants in these accessions accumulating the mutations $\triangle G 210+G 399 A$ and $G 399 A+R 128 G$ (in the same allele), and plants carrying $\Delta G 210+R 128 G$ (may or may not occur in the same allele). How these double mutations might affect the degree of resistance at the plant level is yet to be understood. This study was conducted to evaluate the level of resistance to fomesafen conferred by the ppo 2 mutations $\triangle G 210$ and G399A in PPO-resistant A. palmeri accessions, whether borne in separate plants or in the same plant or allele. The response of these accessions to other foliar-applied PPO herbicides was also evaluated.

\section{Materials and Methods}

\subsection{Fomesafen Dose-Response Assay}

A. palmeri accessions collected in 2017 and 2018 were tested for fomesafen resistance and genotyped for the presence of $\Delta G 210$ and G399A mutations [28]. From this initial test, six populations (collected in 2017 from fields in Arkansas and Missouri) were selected based on their mutation profiles (Table 1). The six PPO-resistant accessions, and a susceptible standard (SS), were used in whole-plant bioassays to determine the resistance level to fomesafen. The accessions were expected to contain $\triangle$ G210 (PHI-C and LAW-E), G399A (PHI-I and SC-C), and both mutations (NM-J and PEM-F). This experiment was conducted in a greenhouse located at the Altheimer Laboratory, University of Arkansas, Fayetteville, USA. Seeds were sown in $11 \times 11 \mathrm{~cm}^{2}$ pots filled with commercial potting soil (Sunshine ${ }^{\circledR}$ Premix No. 1; Sun Gro Horticulture, Bellevue, WA, USA) and thinned to 4 plants pot ${ }^{-1}$. Plants were grown under a $14 / 10$-h photoperiod and $32 / 25 \pm 3{ }^{\circ} \mathrm{C}$ day/night temperature. The experiment was conducted twice and had four replications. Each replication was one pot. Seedlings, 8- to 10-cm tall (4- to 6-leaf stage), were sprayed with 6 doses of fomesafen (Flexstar $^{\circledR}$, Syngenta Crop Protection, Greensboro, NC, USA) from 0 to $1120 \mathrm{~g}$ ai ha ${ }^{-1}$ 
for resistant populations, corresponding to 0 to $4 \times$ the recommended field dose. The dose range for SS was from 0 to $280 \mathrm{~g} \mathrm{ha}^{-1}$, corresponding to 0 to $1 \times$ the recommended dose. Fomesafen was applied with $0.5 \%$ v/v non-ionic surfactant (Induce, Helena Chemical, Collierville, TN, USA). Each replication was sprayed separately in a spray chamber with an air-propelled, motorized boom fitted with 1,100,067 nozzles (Teejet, Wheaton, IL, USA) calibrated to deliver $187 \mathrm{~L} \mathrm{ha}^{-1}$. At 3 weeks after treatment (WAT), plants were evaluated for injury. Visible injury (\%) was rated on a scale of 0 to $100 \%$, where 0 represented no effect, and $100 \%$ was dead $[29,30]$. The data were analyzed by regression using the "drc" package in the software R v. 4.0.3 [31]. A three-parameter log-logistic model was fitted to the data using Equation (1):

$$
Y=d / 1+\exp [b(\log x-\log e)]
$$

where $Y$ is visible injury relative to the nontreated check (\%), $d$ is the upper horizontal asymptote; $b$ is the slope around $e$, which is the herbicide dose causing 50\% injury (ED50); and $x$ is the herbicide dose [32]. The resistance index was the ratio of the ED50 values of the $\mathrm{R}$ accession and SS accession. There was no significant difference among runs; therefore, data from two runs were analyzed together. Injury of survivors (\%) was also recorded to select plants for genotyping.

Table 1. Expected mutation profile of A. palmeri field accessions used in the experiment.

\begin{tabular}{cccc}
\hline Accession & Origin State & $\Delta G 210$ & $G 399 A$ \\
\hline LAW-E ${ }^{\text {a }}$ & Arkansas & Present & Absent \\
NM-J & Missouri & Present & Present \\
PEM-F & Missouri & Present & Present \\
PHI-C & Arkansas & Present & Absent \\
PHI-I & Arkansas & Absent & Present \\
SC-C & Missouri & Absent & Present \\
SS ${ }^{\text {b }}$ & Arkansas & Absent & Absent \\
\hline
\end{tabular}

a The resistant accessions were harvested in 2017. ${ }^{\mathrm{b}}$ The susceptible accession was harvested in 2018.

\subsection{Response to Other Foliar-Applied PPO Herbicides}

The seven accessions (including SS) used in the dose-response assay were also tested with selected PPO herbicides (Table 2). This experiment was conducted in similar conditions as the dose-response assay. A total of 36 seedlings per accession (16 seedlings in the first run and 20 seedlings in the second run), mostly 7- to 10- $\mathrm{cm}$ and 4- to 6-leaf stage, were treated with $1 \times$ and $2 \times$ the recommended doses of PPO herbicides, carfentrazone, flumioxazin, saflufenacil, and trifludimoxazin. Carfentrazone and flumioxazin were sprayed with $0.25 \%$ NIS $(v / v)$. Saflufenacil was applied with $1 \%$ methylated seed oil $(v / v)$ and $1 \%$ ammonium sulfate $(w / v)$. Trifludimoxazin was applied with $1 \%$ methylated seed oil $(v / v)$. Nontreated check was used as reference. Herbicide application followed the methodology explained above. After herbicide application, plants were grouped in the greenhouse by herbicide and dose. The accessions were completely randomized within each dose and herbicide group. At 3 WAT, injury per survivor and mortality (\%) were assessed. Survivors showing injury higher than $90 \%$ were classified as susceptible because such severely injured plants would not survive in the field, in competition with the crop and other weeds. The mortality data were subjected to ANOVA using Proc GLIMMIX function in SAS v. 9.4 (SAS Institute, Cary, NC, USA). Mortality data did not follow a normal distribution based on the Shapiro-Wilk test [33]; therefore, a beta distribution was assumed for this response analysis [34]. Student's $t$ test $(p<0.05)$ was used to compare treatment means. 
Table 2. Common name, trade name, and chemical family of PPO-inhibiting herbicides in the study.

\begin{tabular}{cccc}
\hline Common Name $^{\text {a }}$ & Trade Name & Chemical Family & Field Rate \\
\hline Carfentrazone & & & g ai ha $^{-1}$ \\
\hline Flumioxazin & Aim $^{\circledR}$ 2EC & Aryl triazinone & 280 \\
\hline Fomesafen & Valor $^{\circledR}$ SX 51 WDG & N-phenylphthalimide & 71.5 \\
\hline Saflufenacil & Flexstar $^{\circledR} 1.88$ SL & Diphenyl ether & 280 \\
\hline Trifludimoxazin & Sharpen $^{\circledR} 4 \mathrm{~F}$ & Pyrimidinedione & 25 \\
\hline
\end{tabular}

a Protoporphyrinogen IX oxidase inhibitors. ${ }^{\mathrm{b}}$ Commercial name in Australia; not registered in the USA.

\subsection{Detection of Mutations by TaqMan Genotyping Assay}

DNA was extracted from leaf tissues of selected survivors showing less than $85 \%$ injury from both runs of the "2.1. Fomesafen Dose-Response Assay". Leaf tissues were collected from survivors at $1 \times, 2 \times$, and $4 \times$ the recommended dose of fomesafen ha $^{-1}$ for the accessions LAW-E, NM-J, PEM-F, and PHI-I; at $1 \times$ and $2 \times$ for the accession SC-C; and at $1 \times$ for the accession PHI-C. Following the protocol previously used [28], the tissues were placed separately in 1.5- mL Eppendorf tubes (VWR International LLC, Radnor, PA, USA) with two 2.4-mm metal beads (VWR International LLC). The tubes were stored in $-80{ }^{\circ} \mathrm{C}$ until processed. The tubes with leaf tissues and beads were ground in a laboratory mixer mill (MM400, Retsch GmbH, Haan, Germany) for $15 \mathrm{~s}$ at $30 \mathrm{~Hz}$. Genomic DNA was extracted using a modified CTAB protocol [35] and quantified using a NanoDrop spectrophotometer (Thermo Scientific, Wilmington, DE, USA). The extracted DNA was diluted to about $150 \mathrm{ng} \mathrm{uL}^{-1}$. Plant samples of each accession were genotyped individually for the presence of the target-site mutations $\Delta G 210$ and / or G399A.

DNA samples were diluted to a concentration of $150 \mathrm{ng} \mu \mathrm{L}^{-1}$. The diluted samples were used in the TaqMan ${ }^{\circledR}$ SNP Genotyping Assay. Fluorescent probes were used to discriminate between the resistant and susceptible alleles of the ppo2 ( $\triangle G 210$ and $G 399 A$ ) gene. For $\Delta$ G210 detection, the forward ( $5^{\prime}$-TGATTATGTTATTGACCCTTTTGTTGCG-3 ${ }^{\prime}$ ) and reverse (5'-GAGGGAGTATAATTTATTTACAACCTCCAGAA-3') primer pair was used [23]. Probes overlapping the $\triangle G 210$ mutation, targeting wild type (5'-TTGAGGATCTCCACCACATG-3') and positive $\triangle G 210$ (5'-CGATTGAGGATCTCCACATG-3'), were used [36]. For G399A detection, the forward (5'-TGTTTATTTGATAAACATATCATAGAATCTAATGCTAGTTTCTT-3') and reverse (5'-AGCACGATCAGGAAACATCATAGAC- $3^{\prime}$ ) primers were used. Probes overlapping the G399A mutation, targeting wild type (5'-ACGTCGCAGGTACTTT-3') and positive $\Delta$ G210 (5'-CGTCGCAGCTACTTT-3'), were used [28].

The qPCR reaction mixture $(5.5 \mu \mathrm{L})$ consisted of $1 \mu \mathrm{L}$ GoTaq ${ }^{\circledR}$ Flexi buffer (Promega, Madison, WI, USA), $0.6 \mu \mathrm{L} 25 \mathrm{mM} \mathrm{MgCl}_{2}$ (Promega), $0.25 \mu \mathrm{L} 10 \mathrm{mM}$ dNTP mix (Promega), $0.25 \mu \mathrm{L}$ primer-probe mix (Thermo Fisher Scientific, Waltham, MA, USA), $0.05 \mu \mathrm{L}$ GoTaq ${ }^{\circledR}$ Flexi DNA polymerase (Promega), and $1 \mu \mathrm{L}$ of genomic DNA. The qPCR was conducted using a CFX96 Real-Time PCR machine (Bio-Rad, Hercules, CA, USA) using the following conditions: $3 \mathrm{~min}$ at $95{ }^{\circ} \mathrm{C}$, followed by 40 cycles of $15 \mathrm{~s}$ denaturation at $95^{\circ} \mathrm{C}, 1 \mathrm{~min}$ at $60{ }^{\circ} \mathrm{C}$, followed by a plate read at the end of every cycle. The plates included a known homozygous and heterozygous resistant allele for each mutation and a homozygous susceptible. Allelic discrimination was performed using the Bio-Rad CFX Manager ${ }^{\mathrm{TM}}$ software (BioRad, Hercules, CA, USA) based on the relative fluorescence units. This data was used to describe the profile of individual survivors per accession and dose.

\section{Results}

\subsection{Fomesafen Dose-Response Assay}

To determine the resistance level to fomesafen, a dose-response bioassay was conducted with LAW-E, NM-J, PEM-F, PHI-C, PHI-I, SC-C, and SS accessions. Except for SC-C, none of the resistant accessions were completely controlled at $1 \times$ dose $\left(280 \mathrm{~g} \mathrm{ha}^{-1}\right)$ of fomesafen (Figure 1). Regardless of accession, survivors at $280 \mathrm{~g} \mathrm{ha}^{-1}$ fomesafen showed 
a wide range of injury (from no symptoms to severe plant necrosis and stunting). The approximate fomesafen dose that would cause $50 \%$ injury (ED50) varied widely among the resistant accessions. The ED50 ranged from 55 to $171 \mathrm{~g} \mathrm{ha}^{-1}$ with the order of resistance level as follows: LAW-E > PEM-F $>$ PHI-I $>$ NM-J $>$ PHI-C. The resistance levels (R/S) ranged from 2- to 7-fold (Figure 2). It turned out that SC-C was more sensitive to fomesafen $\left(\right.$ ED50 $\left.=13 \mathrm{~g} \mathrm{ha}^{-1}\right)$ than the SS population $\left(\mathrm{ED} 50=24 \mathrm{~g} \mathrm{ha}^{-1}\right)$. SC-C was included in this test because rare individuals harboring the G399A mutation were detected in this population in the general resistance screening. This case highlights the fact that rare resistant individuals would already have been selected in the field several years prior to detection of field-level resistance [22].

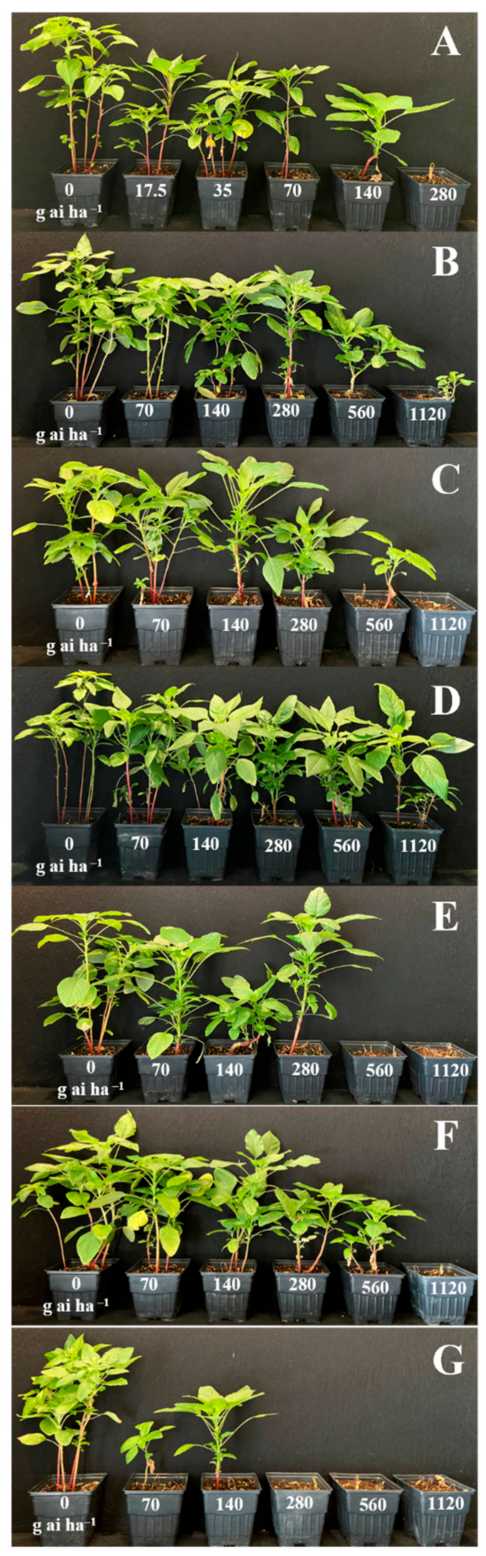

Figure 1. Amaranthus palmeri accessions susceptible and resistant to fomesafen in greenhouse doseresponse experiment. Pictures were taken 3 weeks after treatment with 6 doses of fomesafen, Altheimer Laboratory, University of Arkansas, Fayetteville, USA 2020. Each letter represents one specific accession: (A) susceptible; (B) LAW-E; (C) NM-J; (D) PEM-F; (E) PHI-C; (F) PHI-I; (G) SC-C. The first pot to the left of each photo was nontreated. Fomesafen doses were in $\mathrm{g}$ ai ha ${ }^{-1}$. 


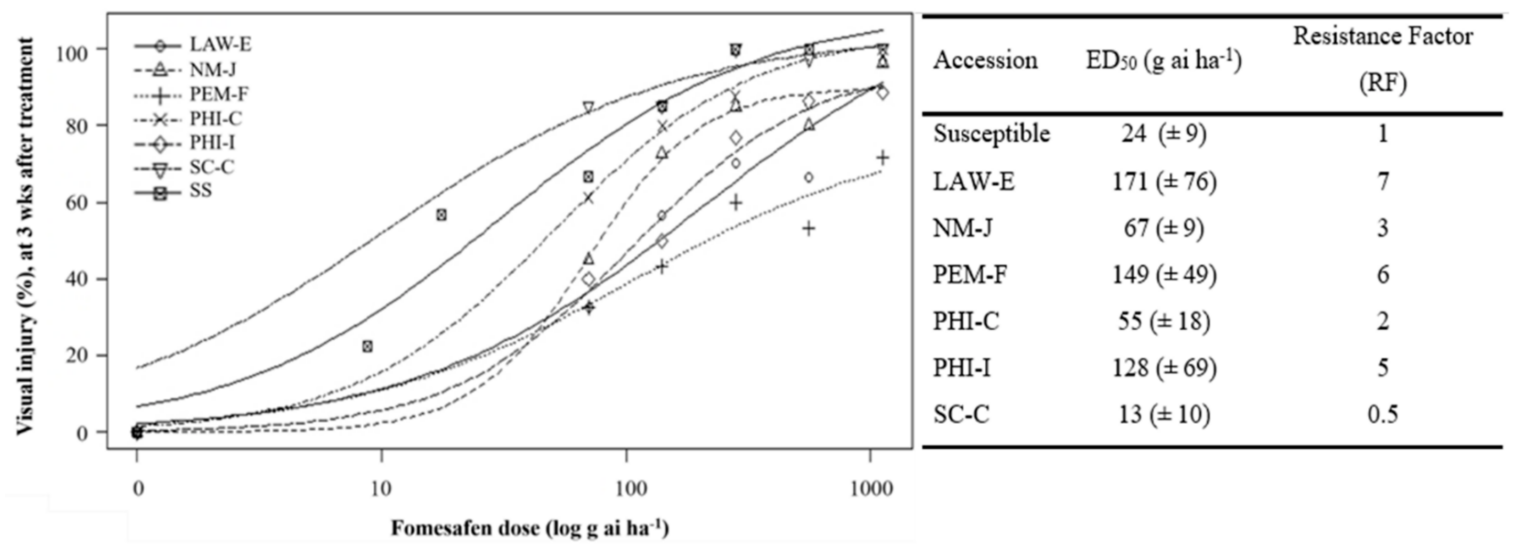

Figure 2. Resistance levels of Amaranthus palmeri accessions to fomesafen in greenhouse bioassays, Altheimer Laboratory, University of Arkansas, Fayetteville, USA 2020. The resistance factor was calculated as the ratio of ED50 R/ED50SS. Symbols and lines represent actual and predicted herbicide injury responses, respectively. Data were fitted to a non-linear, three-parameter $\log$-logistic regression function $Y=d / 1+\exp [\log (x)-\log (e)]$. Values in parenthesis are standard errors of the mean $(p<0.05)$.

\subsection{Response to Other Foliar-Applied Herbicides}

The response of the same accessions to other PPO-inhibiting herbicides tested was as follows: carfentrazone $<$ flumioxazin $<$ saflufenacil < trifludimoxazin. Except for carfentrazone, the interaction between accession and herbicide dose was not significant (Table 3). The accessions differed significantly across all herbicides tested, averaged across doses. The Student's $t$ test $(p<0.05)$ was used to separate accession $\mathrm{x}$ dose interaction means for carfentrazone and the mean injury of accessions in response to all other herbicides (Table 4). At $1 \times$ of carfentrazone, all fomesafen-resistant accessions were more tolerant to the herbicide than SS. PHI-C and SC-C were as susceptible to the $2 \times$ dose of carfentrazone as the SS. Overall, LAW-E and PEM-F were less sensitive than SS to all PPO-inhibiting herbicides tested. However, most survivors of trifludimoxazin treatment, regardless of accession, had $\geq 90$ injury at $21 \mathrm{~d}$ after treatment (data not shown), indicating that such individuals were tougher to kill, but not necessarily resistant. Plants that regrow from this level of injury would be resistant. The resistance frequency and resistance level to trifludimoxazin was low. At $2 \times$ trifludimoxazin, the mortality rates of fomesafen-resistant accessions ranged from 92 to $100 \%$.

Table 3. $p$ values from ANOVA for mortality 3 weeks after treatment with different PPO herbicides.

\begin{tabular}{ccccc}
\hline \multirow{2}{*}{ Factors Evaluated } & \multicolumn{4}{c}{ ANOVA $p$ Values } \\
\cline { 2 - 5 } & Carfentrazone & Flumioxazin & Saflufenacil & Trifludimoxazin \\
\hline Accession & $<0.0001$ & $<0.0001$ & $<0.0001$ & 0.0277 \\
\hline Dose & 0.0002 & 0.1332 & 0.0201 & 0.0556 \\
\hline Acc $\times$ Dose & 0.0389 & 0.5124 & 0.4518 & 0.8619 \\
\hline
\end{tabular}

\subsection{Detection of Mutations by TaqMan Genotyping Assay}

The presence of $\Delta G 210$ and G399A ppo2 mutations was observed in survivors of accessions NM-J, PEM-F, and SC-C (Table 5). PEM-F and SC-C had survivors with both mutations found in the same plant. Only one individual from SC-C survived the $2 \times$ dose of fomesafen, and this plant carried both mutations. This individual was excluded from the other comparisons. Based on the dose-response assay SC-C was sensitive to fomesafen, but it contained rare individuals that are resistant to PPO inhibitors. Accession PEM-F, which also contained plants harboring both ppo2 mutations, was the second most resistant to fomesafen. A total of $32 \%$ of survivors of this accession had both mutations. In all 
survivors genotyped, both mutations were heterozygous. Therefore, $\triangle G 210$ and $G 399 A$ may or may not co-exist in the same allele of the survivors tested.

Table 4. Response of fomesafen-resistant Amaranthus palmeri accessions to the $1 \times$ and $2 \times$ rates of PPO-inhibiting herbicides, Altheimer Laboratory, University of Arkansas, Fayetteville, USA 2020.

\begin{tabular}{|c|c|c|c|c|c|c|c|c|}
\hline \multirow{3}{*}{ Accession } & \multirow{3}{*}{ Dose $^{a}$} & \multicolumn{7}{|c|}{ Mortality } \\
\hline & & Carfentrazone & \multicolumn{2}{|l|}{ Flumioxazin } & \multicolumn{2}{|c|}{ Saflufenacil } & \multicolumn{2}{|c|}{ Trifludimoxazin } \\
\hline & & & & & & & & \\
\hline \multirow{2}{*}{ LAW-E } & $1 \times$ & 27 & 16 & \multirow{2}{*}{ * } & 54 & \multirow{2}{*}{ * } & 87 & \multirow{2}{*}{ * } \\
\hline & $2 \times$ & 31 & 10 & & 78 & & 92 & \\
\hline \multirow{2}{*}{ NM-J } & $1 \times$ & 41 & 18 & \multirow{2}{*}{ * } & 86 & \multirow{2}{*}{ ns } & 90 & \multirow{2}{*}{ ns } \\
\hline & $2 \times$ & 93 & 42 & & 93 & & 94 & \\
\hline \multirow{2}{*}{ PEM-F } & $1 \times$ & 30 & 10 & \multirow{2}{*}{ * } & 75 & \multirow{2}{*}{ * } & 87 & \multirow{2}{*}{ * } \\
\hline & $2 \times$ & 42 & 11 & & 83 & & 94 & \\
\hline \multirow{2}{*}{ PHI-C } & $1 \times$ & 66 & 95 & \multirow{2}{*}{ ns } & 93 & \multirow{2}{*}{ ns } & 100 & \multirow{2}{*}{ ns } \\
\hline & $2 \times$ & 83 & 99 & & 100 & & 100 & \\
\hline \multirow{2}{*}{ PHI-I } & $1 \times$ & 37 & 20 & \multirow{2}{*}{ * } & 93 & \multirow{2}{*}{ ns } & 94 & \multirow{2}{*}{ ns } \\
\hline & $2 \times$ & 58 & 47 & & 92 & & 100 & \\
\hline \multirow{2}{*}{ SC-C } & $1 \times$ & 55 & 87 & \multirow{2}{*}{ ns } & 89 & \multirow{2}{*}{ ns } & 100 & \multirow{2}{*}{ ns } \\
\hline & $2 \times$ & 93 & 96 & & 93 & & 100 & \\
\hline \multirow{2}{*}{$\mathrm{SS}^{\mathrm{b}}$} & $1 \times$ & 100 & 100 & & 100 & & 100 & \\
\hline & $2 \times$ & 100 & 100 & & 100 & & 100 & \\
\hline
\end{tabular}

${ }^{a}$ Recommended field rate $(1 \times)$ per herbicide in $\mathrm{g}$ ai ha ${ }^{-1}$ : carfentrazone, 280, and flumioxazin, 71.5 , with $0.25 \%$ NIS $(v / v)$; saflufenacil, 25 , with $1 \% v / v$ methylated seed oil and $1 \% w / v$ ammonium sulfate; trifludimoxazin, 30 , with $1 \% v / v$ methylated seed oil. ${ }^{b}$ Susceptible population (SS). * Significant difference $(p<0.05)$ compared to susceptible standard. ${ }^{n}$ No significant difference from the susceptible standard.

Table 5. Genotype and zygosity of Amaranthus palmeri survivors from treatments with 280, 560, and $1120 \mathrm{~g}^{-1}$ fomesafen $\left(\right.$ Flexstar $^{\circledR} 1.88$ EC) $+0.5 \%$ v/v NIS surfactant.

\begin{tabular}{|c|c|c|c|c|c|c|c|c|c|c|}
\hline \multirow{2}{*}{ Accession } & \multirow{2}{*}{$\begin{array}{l}\text { No. of Plants } \\
\text { Genotyped }\end{array}$} & \multicolumn{2}{|c|}{$\Delta G 210$ Only } & \multicolumn{2}{|c|}{ G399A Only } & \multirow{2}{*}{$\Delta G 210+G 399 A$} & \multirow{2}{*}{$\mathrm{WT}^{\mathrm{c}}$} & \multicolumn{3}{|c|}{ WT Injury (\%) } \\
\hline & & $\mathbf{R R}^{\mathrm{a}}$ & $R r^{b}$ & RR & $\mathbf{R r}$ & & & Min & $\operatorname{Max}$ & Average \\
\hline LAW-E $^{d}$ & 16 & 11 & 4 & - & - & - & 1 & 50 & 50 & 50 \\
\hline NM-J ${ }^{d}$ & 13 & - & 2 & 2 & 4 & - & 5 & 40 & 70 & 45 \\
\hline PEM-F $^{\mathrm{d}}$ & 22 & 2 & 6 & - & 6 & 7 & 1 & 50 & 50 & 50 \\
\hline PHI-C ${ }^{\mathrm{e}}$ & 4 & - & 2 & - & - & - & 2 & 30 & 30 & 30 \\
\hline PHI-I ${ }^{d}$ & 16 & - & - & - & 1 & - & 15 & 30 & 60 & 46 \\
\hline$S C-C^{f}$ & 4 & - & 1 & 1 & 1 & - & 1 & 50 & 50 & 50 \\
\hline
\end{tabular}

${ }^{a}$ Homozygous; ${ }^{b}$ Heterozygous; ${ }^{c}$ Mechanism of resistance was not investigated.; ${ }^{\mathrm{d}}$ Leaf tissues from survivors of 280,560 and $1120 \mathrm{~g}$ fomesafen $\mathrm{ha}^{-1}$. ${ }^{\mathrm{e}}$ Leaf tissues from survivors of $280 \mathrm{~g}$ fomesafen $\mathrm{ha}^{-1}$. ${ }^{\mathrm{f}}$ Leaf tissues from survivors of 280 and $560 \mathrm{~g}$ fomesafen ha ${ }^{-1}$.

The only ppo2 mutation present in LAW-E and PHI-C survivors was $\Delta$ G210. Based on accession-level responses to fomesafen and to other PPO herbicides, LAW-E had the highest resistance to PPO-inhibitor herbicides. The majority of genotyped survivors from LAW-E (11 out of 16) had homozygous $\Delta$ G210 mutation (Table 5). The high frequency of $\triangle$ G210-homozygous individuals, and the high resistance to PPO inhibitors in this accession, indicate that the occurrence of $\Delta G 210$ mutation on both alleles confers high resistance level to PPO herbicides resulting in $<50 \%$ injury (Figure 3 ). Overall, across accessions, the $\Delta G 210$ mutation was present in most survivors up to the highest dose of fomesafen (1120 $\left.\mathrm{g}_{\text {ai ha }}{ }^{-1}\right)$. 

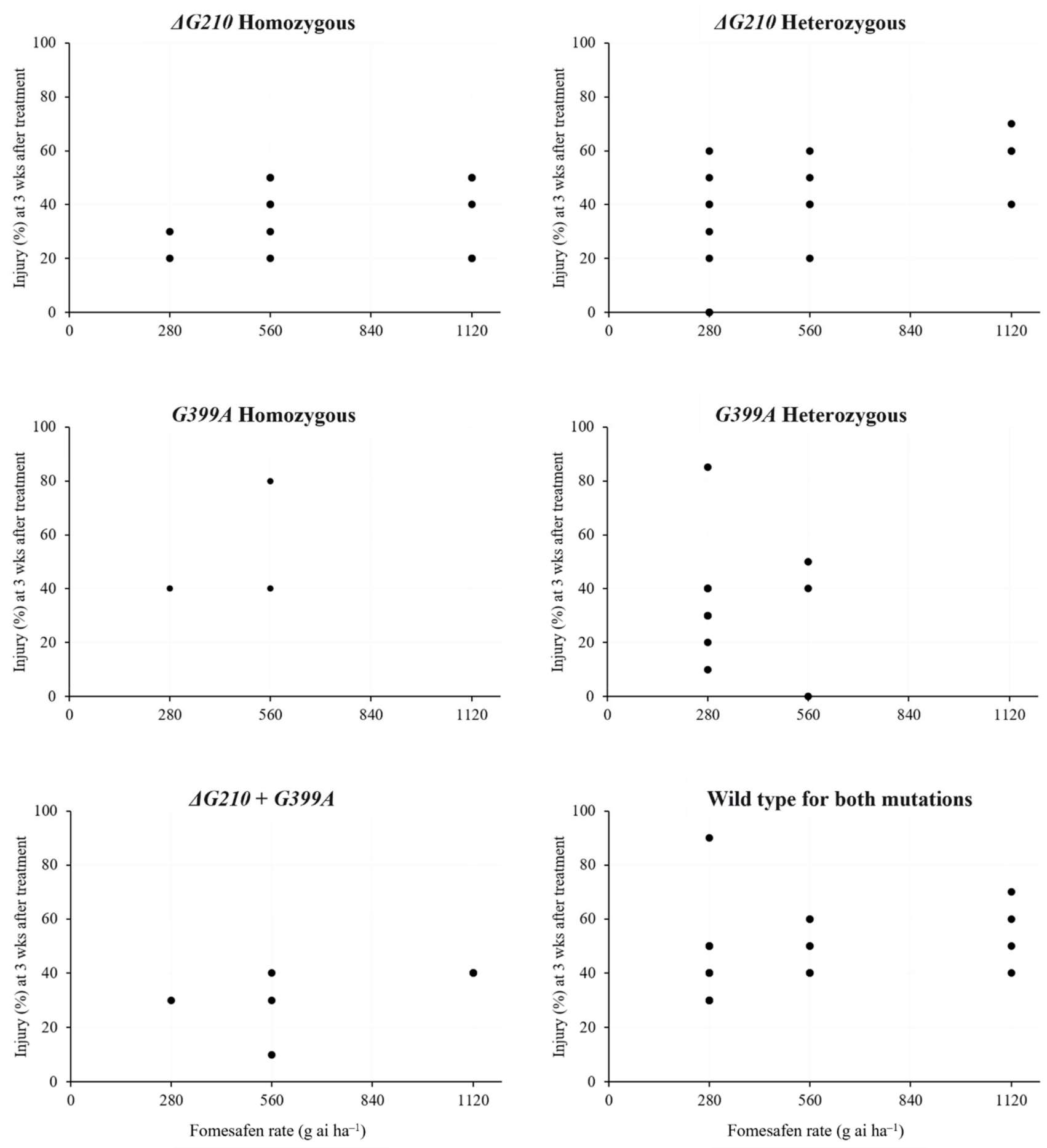

Figure 3. Injury (\%) of Amaranthus palmeri survivors from treatments with 280, 560 and $1120 \mathrm{~g} \mathrm{ha}^{-1}$ fomesafen (Flexstar $^{\circledR}$ $1.88 \mathrm{EC})+0.5 \% v / v$ nonionic surfactant separated by genotype. Each dot in the graphs may represent multiple survivors.

At $4 \times$ fomesafen, survivors that carried $(\Delta G 210+G 399 A)$ or homozygous $\Delta G 210$ mutation incurred similar levels of injury (20 to $50 \%$ ), while the survivors that did not carry $\Delta G 210$ or $G 399 A$ mutation, or those that showed the presence of heterozygous $\Delta G 210$ mutation, incurred a higher injury from 40 up to $70 \%$ (Figure 3). Regardless of accession and fomesafen rate, this pattern was the same across all the genotyped survivors (78 total). This indicates that survivors carrying the $\Delta G 210$ in both alleles and other mutations coexisting with $G 399 A$ will recover better than those with $G 399 A$ alone or those harboring mutations other than $\triangle G 210$ or G399A. 
Unlike $\Delta G 210$, homozygous $G 399 A$ individuals were rare among the populations tested. Only three out of 78 survivors genotyped harbored this mutation in the homozygous state (Table 4). When G399A occurred by itself, the heterozygous survivors incurred $20-80 \%$ injury while the homozygous ones had $40-80 \%$ injury (Figure 3). Thus, the relationship between the occurrence of $p p o 2$ mutation(s) in field-selected plants and resistance level is not straightforward. Of the 16 survivors of $4 \times$ fomesafen, none harbored the G399A mutation by itself, either heterozygous or homozygous.

The accession PHI-I which harbors plants carrying the ppo2 G399A mutation was classified as resistant in the dose-response assay. However, only one out of sixteen survivors exhibited the G399A mutation. The other survivors were wild type for both mutations. Since the PPO2 gene of these plants was not sequenced nor tested for other PPO mutations, the mechanism of resistance in these plants is not known.

\section{Discussion}

\subsection{Resistance Level to Fomesafen and Overall Response to Other Foliar-Applied Herbicides}

The ED50 values estimated in this study were similar to those reported previously for A. palmeri field populations resistant to PPO-inhibitor herbicides. The susceptible population used in this study seemed to have a higher tolerance to fomesafen than the susceptible standards used in previous studies, although direct comparison cannot be made across studies. The resistance index values obtained here were slightly lower compared to those reported in other studies [11,22,26,37]. Wide-ranging ED50 values were also reported for PPO-resistant $A$. palmeri populations from other states. Higher ED50 values (up to $614 \mathrm{~g}$ fomesafen $\mathrm{ha}^{-1}$ ) were estimated for PPO-resistant populations from Kentucky carrying $\Delta G 210$ mutation [38]. On the other hand, low ED50 values (from 12.4 to $28.5 \mathrm{~g}$ fomesafen ha ${ }^{-1}$ ) were reported for populations from Tennessee [27]. Even with low ED50 values, these Tennessee populations had survivors when treated with up to $3360 \mathrm{~g} \mathrm{ha}^{-1}$ fomesafen.

The accessions exhibiting high resistance levels to fomesafen also showed crossresistance to other PPO-inhibitor herbicides. Similar results were previously obtained in studies of different PPO-resistant Amaranthaceae species [11,39,40]. Regarding the overall response to other PPO herbicides, the accessions tested here responded similarly to other A. palmeri accessions tested previously [11]. It was expected that saflufenacil and the newest PPO-inhibitor chemistry, trifludimoxazin, would have the highest levels of control. Saflufenacil is applied pre- and postemergence to field corn, cotton, and soybean to control susceptible broadleaf weeds, including A. palmeri. Previous results showed saflufenacil as a potent herbicide option for A. palmeri [41-43]. However, whenever saflufenacil was applied to fomesafen-resistant populations, its efficacy declined significantly [11,44]. Various crossresistance levels to PPO-chemistries were reported previously among highly fomesafenresistant $A$. palmeri and A. tuberculatus populations $[11,44,45]$. The common pattern is that the great majority of fomesafen-resistant populations are susceptible to saflufenacil, and populations that are cross-resistant to trifludimoxazin have not yet evolved at the field level. However, individuals with cross-resistance to trifludimoxazin have already been selected in a few field populations. A premix formulation of saflufenacil and trifludimoxazin was launched this year in Australia. This formulation is more effective in burndown application than other burndown herbicides and is a promising tool for the control of PPO-herbicidetolerant or -resistant weeds [46-49]. Nevertheless, to curtail further resistance evolution, it is crucial to use this new product with other herbicide modes of action. 


\section{2. ppo2 Mutations Patterns among Survivors: Implications on Cross-Resistance to PPO Herbicides}

The predominance of $\Delta G 210$ mutation among the survivors was expected, since this mutation is predominant among PPO-herbicide-resistant $A$. palmeri and $A$. tuberculatus across the US [11,20,24,28,35]. The mutation G399A occurred in a smaller number of plants. Interestingly, among the survivors from the highest fomesafen dose, none carried the mutation G399A by itself (heterozygous or homozygous). In a previous study, a field population of $A$. palmeri exclusively harboring the G399A mutation also did not survive the $4 \times$ dose (1053 $\mathrm{g} \mathrm{ha}^{-1}$ ) of fomesafen [26]. Thus far, the G399A mutation has been reported in a few $A$. palmeri populations in Arkansas, Kansas, Missouri, and Tennessee [26,28,50]. Further research is necessary to fully characterize the physiological effect of G399A substitution and to see if it contributes to increased resistance levels with complementary resistance mechanisms.

Although several researchers studied the resistance level of plants harboring ppo2 mutations, these studies were conducted with survivors from $1 \times$ doses. Up to this point, data on the ppo 2 mutation profile of individuals surviving higher doses are not yet available. In the highest fomesafen dose used in this study (1120 $\mathrm{g}$ ai ha $\left.{ }^{-1}\right)$, the accumulation of two mutations $(\Delta G 210+G 399 A)$ in heterozygous state and single mutation $(\Delta G 210)$ in homozygous state conferred numerically lower injury levels compared to the other mutation profiles at this dose. Although there is no previous information regarding the level of resistance provided by the accumulation of two resistance-conferring ppo 2 mutations in the same plant, there are some studies showing the effects of multiple mutations. The accumulation of different target site mutations in the same plant has been reported in Eleusine indica (L.) Gaertn also [51]. The EPSPS (5-enolpyruvylshikimate-3-phosphate synthase) mutations P106S and T102I were found to occur in the same allele of glyphosateresistant $E$. indica, conferring high resistance $(180 \times)$ to glyphosate. When compared to the resistant population with plants harboring only the P106S mutation, the double mutant E. indica was $32 \times$ more resistant than the single mutant. On the downside, a severe fitness cost was observed in the double epsps mutant goosegrass plants [52]. Similarly, the accumulation of two als mutations in the same plant was detected in A. palmeri from Arkansas [53]. The authors concluded that the accumulation of ALS mutations did not affect the resistance level since all resistant plants across populations harbor one common mutation (W574L), independent of the combination.

The $\Delta G 210$ mutation, even in the heterozygous state, endows resistance to PPO herbicides [21]. The presence of double mutation $(\Delta G 210+G 399 A)$ in heterozygous state indicates that both mutations most likely occurred in different alleles, given that Palmer amaranth is diploid. Additionally, the survivors that showed homozygous single $\Delta G 210$ mutation had the highest levels of resistance to fomesafen and the populations comprised of this genotype had low mortality across the PPO herbicides tested. Although the number of populations studied here was low, these observations suggest that if both alleles of ppo2 carry a mutation $(\Delta G 210$ homozygous or $\Delta G 210+G 399 A)$, the plant may acquire a higher level of resistance to fomesafen. Additionally, our data indicates that $\Delta G 210$ is more likely to occur alone or in combination with G399A on both alleles. The strong resistance level by individuals carrying homozygous $\Delta G 210$ mutation has been reported previously. Homozygous $\Delta G 210 \mathrm{~F} 1$ crosses of $A$. palmeri had the highest ED50 for fomesafen compared to heterozygous ones and those harboring both $\Delta G 210$ and R128G mutations [54]. The high resistance level of the accession accumulating mutations cannot be solely attributed to this accumulation, since only $32 \%$ of the survivors were carrying both mutations.

One of the accessions that exhibited resistance to fomesafen and to two other PPO herbicides was primarily comporised of wild type individuals for both mutations investigated here. Neither the presence of R128 substitutions nor NTSR mechanisms were investigated in this study. Even though TSR is the prevalent mechanism of resistance among PPO-inhibitor-resistant $A$. palmeri populations, other researchers have reported or suggested the possible existence of NTSR mechanisms based on the absence of target-site mutations in some PPO-herbicide-resistant plants [11,20,22,26,37]. PPO-resistant A. palmeri 
and $A$. tuberculatus populations harboring NTSR mechanisms of resistance were identified in Arkansas and Illinois, respectively, based on plant response to P450 inhibitor application ahead of the PPO herbicides [55,56].

\section{Conclusions}

The ppo2 $\Delta G 210$ mutation is the primary mechanism of resistance to PPO-inhibitor herbicides among A. palmeri accessions. The high frequency of homozygous $\Delta G 210$ carriers confers high population-level resistance to fomesafen, reflected in higher predicted ED50 values for fomesafen. Plants that survive the highest fomesafen rate $\left(1120 \mathrm{~g} \mathrm{ha}^{-1}\right)$, which showed homozygous $\Delta G 210$ or heterozygous $\Delta G 210+G 399 A$, are more resistant than heterozygous $\Delta G 210$ alone. The G399A mutation by itself, either heterozygous or homozygous, was not detected among survivors treated with $1120 \mathrm{~g} \mathrm{ha}^{-1}$ fomesafen; therefore, this mutation may not confer an equal resistance level as homozygous $\Delta G 210$. High frequency of homozygous $\Delta G 210$ plants and individuals accumulating $\Delta G 210+G 399 A$ confers high resistance to PPO herbicides.

Author Contributions: Conceptualization, N.R.-B. and G.R.; screening of resistance, J.H.; data collection, P.C.-M. and G.R.; formal analysis, P.C.-M. and G.R.; funding acquisition, N.R.-B.; investigation, P.C.-M., G.R. and N.R.-B.; methodology, P.C.-M., G.R., J.H., D.F., S.J.B. and N.R.-B.; project administration, N.R.-B.; resources, N.R.-B., D.F. and S.J.B.; supervision, N.R.-B. and G.R.; validation, P.C.-M., G.R. and N.R.-B.; visualization, P.C.-M. and G.R.; writing-original draft, P.C.-M.; writing-review and editing, N.R.-B., G.R. and P.C.-M. All authors have read and agreed to the published version of the manuscript.

Funding: This research received funding from: Cotton Inc., the Arkansas Soybean Promotion Board, and BASF.

Institutional Review Board Statement: Not applicable.

Informed Consent Statement: Not applicable.

Data Availability Statement: Not applicable.

Acknowledgments: The authors thank Matheus Machado Noguera for the background research on PPO resistance of A. palmeri accessions, including the initial screening for resistance and genotyping of resistant populations, leading to the selection of accessions used in this research. The authors also thank Koffi Badou Jeremie Kouame and Isabel Schlegel Werle for their assistance in greenhouserelated work.

Conflicts of Interest: D.F. and S.J.B. are employees of BASF Company. Their contribution to this research was technical, but had no role in the design of the experiment. The remaining authors declare that the research was conducted in the absence of any relationships that could be interpreted as a potential conflict of interest. The authors declare no conflict of interest.

\section{References}

1. Bonny, S. Genetically modified herbicide-tolerant crops, weeds, and herbicides: Overview and impact. Environ. Manag. 2016, 57, 31-48. [CrossRef] [PubMed]

2. Duke, S.O. Taking stock of herbicide-resistant crops ten years after introduction. Pestic. Sci. 2005, 61, 211-218. [CrossRef] [PubMed]

3. Vencill, W.K.; Nichols, R.L.; Webster, T.M.; Soteres, J.K.; Mallory-Smith, C.; Burgos, N.R.; Johnson, W.G.; McClelland, M.R. Herbicide resistance: Toward an understanding of resistance development and the impact of herbicide-resistant crops. Weed Sci. 2012, 60, 2-30. [CrossRef]

4. Christoffers, M.J. Genetic aspects of herbicide-resistant weed management. Weed Technol. 1999, 13, 647-652. [CrossRef]

5. Gaines, T.A.; Duke, S.O.; Morran, S.; Rigon, C.A.; Tranel, P.J.; Küpper, A.; Dayan, F.E. Mechanisms of evolved herbicide resistance. J. Biol. Chem. 2020, 295, 10307-10330. [CrossRef] [PubMed]

6. Heap, I. The International Herbicide-Resistant Weed Database. Available online: http://www.weedscience.org/ (accessed on 12 February 2021).

7. Franssen, A.S.; Skinner, D.Z.; Al-Khatib, K.; Horak, M.J.; Kulakow, P.A. Interspecific hybridization and gene flow of ALS resistance in Amaranthus species. Weed Sci. 2001, 49, 598-606. [CrossRef] 
8. Molin, W.T.; Nandula, V.K.; Wright, A.A.; Bond, J.A. Transfer and expression of ALS inhibitor resistance from Palmer amaranth (Amaranthus palmeri) to an A. spinosus $\times$ A. palmeri hybrid. Weed Sci. 2016, 64, 240-247. [CrossRef]

9. Steckel, L.E. The dioecious Amaranthus spp.: Here to stay. Weed Technol. 2007, 21, 567-570. [CrossRef]

10. Chaudhari, S.; Varanasi, V.K.; Nakka, S.; Bhowmik, P.C.; Thompson, C.R.; Peterson, D.E.; Currie, R.S.; Jugulam, M. Evolution of target and non-target based multiple herbicide resistance in a single Palmer amaranth (Amaranthus palmeri) population from Kansas. Weed Technol. 2020, 34, 447-453. [CrossRef]

11. Salas-Perez, R.A.; Burgos, N.R.; Rangani, G.; Singh, S.; Refatti, J.P.; Piveta, L.; Tranel, P.J.; Mauromoustakos, A.; Scott, R.C. Frequency of Gly-210 deletion mutation among protoporphyrinogen oxidase inhibitor-resistant Palmer amaranth (Amaranthus palmeri) populations. Weed Sci. 2017, 65, 718-731. [CrossRef]

12. Spaunhorst, D.J.; Nie, H.; Todd, J.R.; Young, J.M.; Young, B.G.; Johnson, W.G. Confirmation of herbicide resistance mutations Trp574Leu, $\triangle$ G210, and EPSPS gene amplification and control of multiple herbicide-resistant Palmer amaranth (Amaranthus palmeri) with chlorimuron-ethyl, fomesafen, and glyphosate. PLoS ONE 2019, 14, e0214458. [CrossRef]

13. Jacobs, J.M.; Jacobs, N.J.; Sherman, T.D.; Duke, S.O. Effect of diphenyl ether herbicides on oxidation of protoporphyrinogen to protoporphyrin in organellar and plasma membrane enriched fractions of barley. Plant Physiol. 1991, 97, 197-203. [CrossRef]

14. Lee, H.J.; Duke, M.V.; Duke, S.O. Cellular localization of protoporphyrinogen-oxidizing activities of etiolated barley (Hordeum vulgare L.) leaves (relationship to mechanism of action of protoporphyrinogen oxidase-inhibiting herbicides). Plant Physiol. 1993, 102, 881-889. [CrossRef]

15. Matringe, M.; Camadro, J.M.; Labbe, P.; Scalla, R. Protoporphyrinogen oxidase as a molecular target for diphenyl ether herbicides. Biochem. J. 1989, 260, 231-235. [CrossRef]

16. Orr, G.L.; Hess, F.D. Mechanism of action of the diphenyl ether herbicide acifluorfen-methyl in excised cucumber (Cucumis sativus L.) cotyledons: Light activation and the subsequent formation of lipophilic free radicals. Plant Physiol. 1982, 69, 502-507. [CrossRef]

17. Poulson, R.; Polglase, W.J. The enzymic conversion of protoporphyrinogen IX to protoporphyrin IX. Protoporphyrinogen oxidase activity in mitochondrial extracts of Saccharomyces cerevisiae. J. Biol. Chem. 1975, 250, 1269-1274. [CrossRef]

18. Lermontova, I.; Kruse, E.; Mock, H.P.; Grimm, B. Cloning and characterization of a plastidal and a mitochondrial isoform of tobacco protoporphyrinogen IX oxidase. Proc. Natl. Acad. Sci. USA 1997, 94, 8895-8900. [CrossRef]

19. Watanabe, N.; Che, F.S.; Iwano, M.; Takayama, S.; Yoshida, S.; Isogai, A. Dual targeting of spinach protoporphyrinogen oxidase II to mitochondria and chloroplasts by alternative use of two in-frame initiation codons. J. Biol. Chem. 2001, 276, 20474-20481. [CrossRef]

20. Copeland, J.D.; Giacomini, D.A.; Tranel, P.J.; Montgomery, G.B.; Steckel, L.E. Distribution of PPX2 mutations conferring PPOinhibitor resistance in Palmer amaranth populations of Tennessee. Weed Technol. 2018, 32, 592-596. [CrossRef]

21. Patzoldt, W.L.; Hager, A.G.; McCormick, J.S.; Tranel, P.J. A codon deletion confers resistance to herbicides inhibiting protoporphyrinogen oxidase. Proc. Natl. Acad. Sci. USA 2006, 103, 12329-12334. [CrossRef]

22. Salas, R.A.; Burgos, N.R.; Tranel, P.J.; Singh, S.; Glasgow, L.; Scott, R.C.; Nichols, R.L. Resistance to PPO-inhibiting herbicide in Palmer amaranth from Arkansas. Pest Manag. Sci. 2016, 72, 864-869. [CrossRef]

23. Giacomini, D.A.; Umphres, A.M.; Nie, H.; Mueller, T.C.; Steckel, L.E.; Young, B.G.; Scott, R.C.; Tranel, P.J. Two new PPX2 mutations associated with resistance to PPO-inhibiting herbicides in Amaranthus palmeri. Pest Manag. Sci. 2017, 73, 1559-1563. [CrossRef]

24. Varanasi, V.K.; Brabham, C.; Norsworthy, J.K.; Nie, H.; Young, B.G.; Houston, M.; Barber, T.; Scott, R.C. A statewide survey of PPO-inhibitor resistance and the prevalent target-site mechanisms in Palmer amaranth (Amaranthus palmeri) accessions from Arkansas. Weed Sci. 2018, 66, 149-158. [CrossRef]

25. Rousonelos, S.L.; Lee, R.M.; Moreira, M.S.; VanGessel, M.J.; Tranel, P.J. Characterization of a common ragweed (Ambrosia artemisiifolia) population resistant to ALS- and PPO-inhibiting herbicides. Weed Sci. 2012, 60, 335-344. [CrossRef]

26. Rangani, G.; Salas-Perez, R.A.; Aponte, R.A.; Knapp, M.; Craig, I.R.; Mietzner, T.; Langaro, A.C.; Noguera, M.M.; Porri, A.; Roma-Burgos, N. A novel single-site mutation in the catalytic domain of protoporphyrinogen oxidase IX (PPO) confers resistance to PPO-inhibiting herbicides. Front. Plant Sci. 2019, 10, 568. [CrossRef]

27. Wu, C.; Goldsmith, M.R.; Pawlak, J.; Feng, P.; Smith, S.; Navarro, S.; Perez-Jones, A. Differences in efficacy, resistance mechanism and target protein interaction between two PPO inhibitors in Palmer amaranth (Amaranthus palmeri). Weed Sci. 2020, 68, 105-115. [CrossRef]

28. Noguera, M.M.; Rangani, G.; Heiser, J.; Bararpour, T.; Steckel, L.E.; Betz, M.; Porri, A.; Lerchl, J.; Zimmermann, S.; Nichols, R.L.; et al. Functional PPO2 mutations: Co- occurrence in one plant or the same ppo2 allele of herbicide-resistant Amaranthus palmeri in the US Mid-south. Pest Manag. Sci. 2020, 77, 1001-1012. [CrossRef]

29. Burgos, N.R.; Tranel, P.J.; Streibig, J.C.; Davis, V.M.; Shaner, D.; Norsworthy, J.K.; Ritz, C. Confirmation of resistance to herbicides and evaluation of resistance levels. Weed Sci. 2013, 61, 4-20. [CrossRef]

30. Frans, R.; Talbert, R.; Marx, D.; Crowley, H. Experimental design and techniques for measuring and analyzing plant responses to weed control practices. In Southern Weed Science Society, Research Methods in Weed Science; Camper, N.D., Ed.; Weed Science Society of America: Champaign, IL, USA, 1986; pp. 29-46.

31. Ritz, C.; Baty, F.; Streibig, J.C.; Gerhard, D. Dose-response analysis using R. PLoS ONE 2015, 10, e0146021. [CrossRef] 
32. Ritz, C. Toward a unified approach to dose-response modeling in ecotoxicology. Environ. Toxicol. Chem. 2010, 29, 220-229. [CrossRef]

33. Shapiro, S.S.; Wilk, M.B. An analysis of variance test for normality (complete samples). Biometrika 1965, 52, 591-611. [CrossRef]

34. Gbur, E.E.; Stroup, W.W.; McCarter, K.S.; Durham, S.; Young, L.J.; Christman, M.; West, M.; Kramer, M. Analysis of Generalized Linear Mixed Models in the Agricultural and Natural Resources Sciences; American Society of Agronomy, Soil Science Society of America, Crop Science Society of America: Madison, WI, USA, 2012; pp. 7-58.

35. Doyle, J.J.; Doyle, J.L. A rapid DNA isolation procedure for small quantities of fresh leaf tissue. Phytochem. Bull. 1987, 19, 11-15.

36. Wuerffel, R.J.; Young, J.M.; Lee, R.M.; Tranel, P.J.; Lightfoot, D.A.; Young, B.G. Distribution of the $\Delta$ G210 protoporphyrinogen oxidase mutation in Illinois waterhemp (Amaranthus tuberculatus) and an improved molecular method for detection. Weed Sci. 2015, 63, 839-845. [CrossRef]

37. Varanasi, V.K.; Brabham, C.; Korres, N.E.; Norsworthy, J.K. Nontarget site resistance in Palmer amaranth [Amaranthus palmeri (S.) Wats.] confers cross-resistance to protoporphyrinogen oxidase-inhibiting herbicides. Weed Technol. 2019, 33, 349-354. [CrossRef]

38. Lillie, K.J.; Giacomini, D.A.; Tranel, P.J. Comparing responses of sensitive and resistant populations of Palmer amaranth (Amaranthus palmeri) and waterhemp (Amaranthus tuberculatus var. rudis) to PPO inhibitors. Weed Technol. 2019, 34, 140-146. [CrossRef]

39. Shoup, D.E.; Al-Khatib, K.; Peterson, D.E. Common waterhemp (Amaranthus rudis) resistance to protoporphyrinogen oxidaseinhibiting herbicides. Weed Sci. 2003, 51, 145-150. [CrossRef]

40. Huang, Z.; Cui, H.; Wang, C.; Wu, T.; Zhang, C.; Huang, H.; Wei, S. Investigation of resistance mechanism to fomesafen in Amaranthus retroflexus L. Pestic. Biochem. Physiol. 2020, 165, 104560. [CrossRef]

41. Sharpen Herbicide Product Label. Research Drive; BASF Corporation: Florham Park, NJ, USA, 2020; Available online: http: //www.cdms.net/ldat/ld99E001.pdf (accessed on 12 March 2021).

42. Montgomery, G.B.; Bond, J.A.; Golden, B.R.; Gore, J.; Edwards, H.M.; Eubank, T.W.; Walker, T.W. Evaluation of saflufenacil in drill-seeded rice (Oryza sativa). Weed Technol. 2014, 28, 660-670. [CrossRef]

43. Morichetti, S.; Ferrell, J.; MacDonald, G.; Sellers, B.; Rowland, D. Weed management and peanut response from applications of saflufenacil. Weed Technol. 2012, 26, 261-266. [CrossRef]

44. Houston, M.M.; Norsworthy, J.K.; Barber, T.; Brabham, C. Field evaluation of preemergence and postemergence herbicides for control of protoporphyrinogen oxidase-resistant Palmer amaranth (Amaranthus palmeri S. Watson). Weed Technol. 2019, 33, 610-615. [CrossRef]

45. Evans, C.M.; Strom, S.A.; Riechers, D.E.; Davis, A.S.; Tranel, P.J.; Hager, A.G. Characterization of a waterhemp (Amaranthus tuberculatus) population from Illinois resistant to herbicides from five site-of-action groups. Weed Technol. 2019, 33, 400-410. [CrossRef]

46. BASF Corporation. Voraxor Herbicide Product Label. Available online: https://agro.basf.ca/basf/agprocan/agsolutions/ solutions.nsf/Images/PDC-CREO-BZ8N4V/\$File/Voraxor_Product_Label.pdf (accessed on 12 March 2021).

47. Bi, B.; Wang, Q.; Coleman, J.J.; Porri, A.; Peppers, J.M.; Patel, J.D.; Betz, M.; Lerchl, J.; McElroy, J.S. A novel mutation A212T in chloroplast protoporphyrinogen oxidase (PPO1) confers resistance to PPO inhibitor oxadiazon in Eleusine indica. Pest Manag. Sci. 2020, 76, 1786-1794. [CrossRef]

48. Wang, D.W.; Zhang, R.B.; Yu, S.Y.; Liang, L.; Ismail, I.; Li, Y.H.; Xu, H.; Wen, X.; Xi, Z. Discovery of novel N-isoxazolinylphenyltriazinones as promising protoporphyrinogen IX oxidase inhibitors. J. Agric. Food Chem. 2019, 67, 12382-12392. [CrossRef]

49. Armel, G.R.; Hanzlik, K.; Witschel, M.; Hennigh, D.S.; Bowe, S.; Simon, A.; Liebl, R.; Mankin, L. Trifludimoxazin: A new PPO inhibitor that controls PPO resistant weed biotypes. In Proceedings of the Weed Science Society of America, Tucson, AZ, USA, 6-9 February 2017; p. 218.

50. Montgomery, J.S.; Giacomini, D.A.; Tranel, P.J. Molecular confirmation of resistance to PPO inhibitors in Amaranthus tuberculatus and Amaranthus palmeri, and isolation of the G399A PPO2 substitution in A. palmeri. Weed Technol. 2020, 35, 1-7. [CrossRef]

51. Yu, Q.; Jalaludin, A.; Han, H.; Chen, M.; Sammons, R.D.; Powles, S.B. Evolution of a double amino acid substitution in the 5-enolpyruvylshikimate-3-phosphate synthase in Eleusine indica conferring high-level glyphosate resistance. Plant Physiol. 2015, 167, 1440-1447. [CrossRef]

52. Han, H.; Vila-Aiub, M.M.; Jalaludin, A.; Yu, Q.; Powles, S.B. A double EPSPS gene mutation endowing glyphosate resistance shows a remarkably high resistance cost. Plant Cell Environ. 2017, 40, 3031-3042. [CrossRef]

53. Singh, S.; Singh, V.; Salas-Perez, R.A.; Bagavathiannan, M.V.; Lawton-Rauh, A.; Roma-Burgos, N. Target-site mutation accumulation among ALS inhibitor-resistant Palmer amaranth. Pest Manag. Sci. 2019, 75, 1131-1139. [CrossRef]

54. Brabham, C.; Varanasi, V.; Norsworthy, J.K. The level of PPO-inhibitor resistance conferred by different mutations in Palmer amaranth. In Proceedings of the 71st Annual Meeting of the Southern Weed Science Society, Atlanta, GE, USA, 22-24 January 2018; p. 18.

55. Obenland, O.A.; Ma, R.; O’Brien, S.R.; Lygin, A.V.; Riechers, D.E. Carfentrazone-ethyl resistance in an Amaranthus tuberculatus population is not mediated by amino acid alterations in the PPO2 protein. PLoS ONE 2019, 14, e0215431. [CrossRef]

56. Varanasi, V.K.; Brabham, C.; Norsworthy, J.K. Confirmation and characterization of non-Target site resistance to fomesafen in Palmer amaranth (Amaranthus palmeri). Weed Sci. 2018, 66, 702-709. [CrossRef] 